\title{
Development and Validation of Faculty Members' Efficacy Inventory in Higher Education
}

\author{
Shavaran, Sayed Hamid Reza \\ Doctor of Philosophy, School of Educational Sciences and Psychology \\ University of Isfahan, 81746-73441, Iran
}

Tel: 98-311-793-4192Ｅ-mail: rezashavaran@yahoo.com

Rajaeepour, Saeed

Faculty member, School of Educational Sciences and Psychology

University of Isfahan, 81746-73441, Isfahan, Iran

E-mail: srajaeepour@gmail.com

Kazemi, Iraj

Faculty Member, School of Statistics and Mathematics

University of Isfahan, 81746-73441 Isfahan, Iran

E-mail: I.Kazemi@stat.ui.ac.ir

Zamani, Bibi Eshrat

Faculty member, School of Educational Sciences and Psychology

University of Isfahan, 81746-73441, Isfahan, Iran

E-mail: bzamani@edu.ui.ac.ir

Received: September 18, 2011 Accepted: October 27, $2011 \quad$ Published: April 1, 2012

doi:10.5539/ies.v5n2p175 URL: http://dx.doi.org/10.5539/ies.v5n2p175

\begin{abstract}
The purpose of this study was to provide an exploratory investigation of faculty member's efficacy inventory in higher education. Review of the literature showed a few studies about this subject and current instruments did not consider the theoritical foundations of faculty member efficacy. Moreover, most researches were limited to schools area and K-12. After an extensive review of the literature, first, a set of items to operationalize faculty perceptions and beliefs of efficacy in their tasks was developed. At second stage, higher education colleagues who were working in our university and other nearby universities examined the items for critique, and consulted with their colleagues about content and face validity. Third, a pilot study was initiated to map the domain of the construct and refined the measure and the meaning of faculty efficacy through the statistical methods. The instrument was field-tested and refined using a representative sample of universities faculty. Fourth, a factor analysis was utilized to identify factors related to efficacy scale of faculty members. Fifth, we reduced items and agreed about 18. Four factors were appeared in the factor analysis consisting of teaching competencies, research competencies, social competencies, and personal competencies. We insured all four sources of efficacy (mastery experiences, vicarious experiences, social persuasion, and emotional arousal) were represented in each efficacy components (teaching competencies, research competencies, social competencies and personal competencies). Cronbach's alpha coefficient was calculated for each factor and in overall the instrument was a reliable scale 0.83 . Finally, differences between faculty members were studied based on some demographic variables such as gender and academic ranking. Results showed that there were not significant differences between all female and male faculty members efficacy and so based on academic ranking.
\end{abstract}

Keyword: Efficacy, Faculty members, Higher education, Inventory, Development and validation 


\section{Introduction}

New progresses and extensive developments of world today have caused significant changes in social systems. Following these developments, education has also been subjected to extensive changes and has been especial attention to the universities. In fact, opening up new areas and expanding frontiers of knowledge, creativity, innovation and training of professionals has become a priority. Need for dynamic change and adaptation, quality growth has caused university officials' prime attention. As faculty members are factors affecting the quantitative and qualitative development of universities, therefore their perceptions, beliefs, behaviors and their working conditions and occupational environment can help achieve the research and educational objectives, and their personal development to be followed.On the other hand, "In a time when more and more students are coming to the university and concerns such as grade inflation, plagiarism, and academic dishonesty are becoming more salient, it seems pertinent that we begin to look at the motivations and beliefs of the professionals who guide the learning process at this level" (Fives and Looney, 2009, p.182). Of course "behavior in organizations is not simply a function of formal expectations and individual needs and motivation. The relationships among these elements are dynamic. Participants bring to the workplace a host of unique values, needs, goals, and beliefs. These individual characteristics mediate the rational aspects of organizational life. Moreover, a collective sense of identity emerges that transforms a simple aggregate of individuals into a distinctive workplace personality. This indigenous feel of the workplace has been analyzed and studied under a variety of labels, including organizational character, milieu, atmospher, ideology, climate, culture, emergent system and informal organization" (Hoye and Miskel, 2003, p. 163). One of these feelings and beliefs includes efficacy.

If people have confidence in their capabilities, they will have a positive judgment about themselves, and this judgment would be led to efficacy. Two type of efficacy beliefs have been identified as integral to education; these are teacher-efficacy and collective-efficacy. "Teacher-efficacy has been identified as a crucial coustruct in the research on teachers and teaching" (Fives and Looney, 2009, p. 182), whereas, collective-efficacy has only recently begun to receive attention with regard to its role in educational setting (Goddard, 2001). Efficacy beliefs can affect goal setting, motivation, ability and presistance in confronting the existing challenges. We consider the role of university faculty members to be different from the role of school teachers who are associated with students. The material ahead include a summary of the formation of efficacy and efficacy sources.

\section{Conceptual Background}

\section{Efficacy, Teacher efficacy and their sources}

After reviewing the theoretical background of efficacy, it has found that many studies have been limited to school area. Few studies are examined this important construction in the higher education. In fact, very few studies have investigated the influence of efficacy among the faculty members in college and the university level (e.g. Heppner, 1992; Preito and Meyers, 1999; Young and Kline, 1996; Loup, Clarke and Ellett, 1997; Fives and Looney, 2009).

\subsection{Self -Efficacy}

Efficacy is a psychological concept, and is associated with beliefs and attitudes of persons. Therefore, Bandura's social learning theory (1986) is suitable as an entry point. According to Bandura (1997) self efficacy is the "beliefs in one's capabilities to organize and execute the course of action required to produce given attainments" (p.2). In other words, self-efficacy refers to people's judgments of their capabilities to organize and execute courses of action required to attain designed types of performances. Self-efficacy has been emerging in educational research primarily in the areas of career choices (Bandura, 1993; Bandura et al., 2001; Paulsen and Betz, 2004), instructional practices (Ashton, 1985; Gibson and Dembo, 1984; Rimm- Kaufman and Sawyer, 2004; Tucker and Herman, 2002), and motivation and perfomance (Bandura, Barbaranelli et al., 1996 ; Bong \& Skaalvik, 2003; Bouffard \& Couture, 2003; Marsh et al., 2005; Pajares and Miller, 1995). Self-efficaey is not a focus on one's experts or competence but rather on the belief about what can be accomplished (Bong and Schaalvik, 2003).

\subsection{Teacher-Efficacy}

Teacher-efficacy refers to how well teachers believe they can influence student learning. In the teaching context, teacher efficacy is expected to influence the goals teacher identity for the learning context as well as to guide the amounuts of effort and presistence given to the task (Bandura, 1997; Tschannen-Moran, Woolfolk-Hoy and Hoy, 1998). "The efficacy of teachers has become an important area of the effective schools research" (Petersen, $2008, P$. 35). Bandura (1993) suggested that when teachers feel confident and validated in their abilities to teach students, their teaching strategies, relationships with peers and students, and personal expectations for the student performance are similarly embedded with positive expectations.

Woolfok-Hoy (2004 a) stated: 'One of things that makes teachers' efficacy judgments so powerful is the cyclical 
nature of the process. Greater efficacy leads to greater effort and presistence, which leads to better performance mastery, which in turn leads to greater efficacy. The reverse is also true. Lower efficacy leads to less effort and giving up easily, which leads to poor teaching outcomes, which then produces decreased efficacy" (P.7). Several studies indicated that teachers with a strong sense of confidence are less likely to refer students for special education services (Meijer \& Foster, 1988; Soodak \& podell, 1993 a, 1993b). Moreover, efficacious teachers also feel more prepared to teach culturally diverse students (Tucker et al., 2005). Tschannen-Moran and Woolfolk -Hoy (2007) suggest that experienced teachers also gain efficacy as they aquire successful teaching strategies along the way. Hoy \& Woolfolk (1993) found: “... teachers who went to graduate school for further education were more likely to have a sense of personal teaching efficacy" (p. 367). In brief, "teacher - efficacy refers to the teacher's belief in his or her capability to organize and execute courses of action required to successfully accomplish a specific teaching task in a particular context"(Tschannen- Moran, Woolfolk -Hoy, and Hoy, 1998, p. 233). Pajares (1992) contended that " beliefs are the best indicators of the decisions individuals make throughout their lives" (P. 307). Thus, it is an indicator of their future behaviors, decisions, and classroom organization.

\subsection{Sources of Efficacy}

There are four sources which develop people efficacy. These sources are: mastery experiences, vicarious experiences, social influence, and emotional stimulation (Bandura, 1977a, 1986, 2000c).

Successful performance of a task using personal skill and effort provides the most impact toward the growth of an individual's self-efficacy. Successes build strong beliefs in a faculty's sense of efficacy, while, repeated failure diminishes efficacy and causes one to expect failure in prospective attempts (Pajares, 2000; Tschannen-Moran and Woolfolk Hoy, 1998). If success, however, is frequent and easy, failure is likely to produce discouragement. A person continued success with a task also makes an occasional failure less of a barrier (Bandura, 1977a, 2000c). Success in task mastery is vital in developing strong personal efficacy. It not only gives the individual a sense of accomplishment, but also increases the probability of replication (Petersen, 2008).

Direct experiences in not the only way that staff can build its efficacy. "Vicarious experiences can increase efficacy beliefs, too" (Gage 2003, p. 69). Teachers listen to stories about the accomplishments of their colleagues as well as stories of other organizations. In this experience, the individuals gain efficacy through observing someone else model a task (Bandura, 1977a). Vicarious experience and modeling serves as an effective sources of personal efficacy.

The responses one gets from peers, family, co-worker, and other influentials can enhance or harm the individuals self efficacy progress. Gage (2003) suggessted "the faculty can be changed and efficacy beliefs strengthed through a variety of different methods. Reporting successes to the group, attending professional development, pep talks, positive notes in mailboxes, and similar gestures can work to increase levels of collective-efficacy " (p. 70).

How well the individual feels about what can be accomplished makes an impact on the effort exerted and persistence employed. "Physiological and emotional orientation influences one's sense of proficiency, competence and accomplishment"(Petersen, 2008, P.19).The affective condition has a strong bearing on one's approach toward a task. It shapes how one interpret the task and, ultimately, impacts the individual's personal efficacy (Goddard, 1998; Goddard et al., 2004).

Achievement of the university mission depends on the intention and ability of faculties. Therefore focus on perceptions, beliefs and workplace of faculty members is an issue for further study and research. Faculty member beliefs about their capabilities, can prepare them for the main tasks of universities, including education, research and service, and helps students possessing creative and critical thinking and deep understanding about their scientific fields and obtaining tasks and jobs that are available in community. The findings of past researches in K-12 public schools have showed two different aspects of teacher-efficacy including personal and teaching efficacy (Gibson and Dembo, 1984; Guskey and Passaro, 1994).

Studies conducted in the schools have shown that there is a significant and positive relationship between student achievement and teacher efficacy (Ross et al., 2001; Moore and Esselman, 1992), but a few studies have examined efficacy among university level instructors. Researchers have investigated the role of self-efficacy in improving university-level teaching (i.e., Heppner, 1992; Preito and Meyers, 1999; Young \& Kline, 1996;). One focus in these researches has been on the trining of Graduate Teaching Assistants (GTAs) and the influence formal training has on the development of their self efficacy for teaching (Heppner, 1992; Preito and Meyers, 1999; Fives \& Looney, 2009). Fives and Looney (2009) stated: Other researchers about self efficacy in university faculty have provided descriptions of efficacy by gender (Bernnan, Robison and Shaughnessy, 1996; Landino and Owen,1988; Schoen and Winocur,1988) professional ranks (Schoen and Winocur,1988) and age, experience and gender make-up of academic departments"(p.183). 
It seems that current instruments have not considered the theoretical foundations of this construct. But what about faculty member-efficacy in higher education? Does faculty member-efficacy serve to abet the effort of colleges to achieve their goals? Are there differences in the efficacy levels of various university faculty members? Given the work environment of higher education institutions where individual autonomy is interfaced with organizational interdependence, it has belived that faculty member efficacy merits is an important area for exploration. Therefore, the purpose of this research was two fields. First, we conceptualized and field-tested an instrument to guage perceptions of faculty members-efficacy about their works. Secound, this study attempts to address differences in faculty members efficacy across gender and academic rank. A survey of perceptions and beliefs of the faculties efficacy based on these variables can help chancellors, deans and faculties to communicate the results towards enhancing and improving the campus space and culture and promoting the faculty members performance and productivity efforts. In brief, three general research questions guided this study.

\subsection{Research Questions}

1. What are the dimensions of faculty member-efficacy in higher education institiutions?

2. Are there statistically significant differences between female and male faculty members-efficacy levels in higher education institutions?

3. Are there statistically significant differences between faculty members-efficacy based on academic ranks in higher education institutions?

\subsubsection{First question: What are the dimensions of faculty member efficacy in higher education institutions?}

The theoretical base from which the efficacy items were conceived was primarily developed by Gibson and Dembo (1984) and was further developed by Tschnnen-Moran and Woolfolk-Hoy (2001).The items needed for the instrument were developed in collaboration with faculty members in education and pchycology departments, other experts, and doctoral students in selected public universities. The development of the instrument went through a series of phases before the final product was produced.

First, a pool of items was generated. Second, a panel of experts reacted to the items.Third, two pilot studies were performed to identify and refine the factor structure. Fourth, reliability and validity of the instrument were tested. Finaly, a survey study based on some demographic characteristics was performed.These steps will be described in more detail in the following sections.

\subsubsection{Item Generation}

Items generated and shaped based on efficacy literature review, which deal with individual capabilities and main task of faculty members at universities. These items gauged the extent to which faculty members have believed in their capabilities to organize and execute actions required for goal attainments. The main tasks and roles of faculty members consist of student teaching, research on academic courses and interaction with other individuals in academic environment. Finally, four aspects for faculty members-efficacy formulated including: teaching competency, research competency, social competency and personal competency.

Initially, 94 statements were conceived by researchers, approximately 20-25 for each of the dimensions of faculty member capabilities, duties and relationships. These statements were subsequently given to twelve professors of education and pchycology, and other experts, to review for clarity and face validity. The items attempted to capture faculty members-efficacy with concise, accurate descriptors of faculty members beliefs and attitudes.

\subsection{Panel of Experts}

Twelve faculty members in education and pchycology departments and a $\mathrm{PhD}$ student were asked to check the face and content validity of the statements. The goal was to determine which questions captured the theoretical notion of faculty member efficacy. The items which there had agreement among the panel were selected for the pilot test. The 94 statements were reduced to 44 statements, between 8 and 14 statements for each suggested dimension of faculty member efficacy. Finally a ten point scale was devised for the respondents to rate each statement from strongly disagree (1) to strongly agree (10).

\subsection{Field Test}

Prior to the final testing, an informal field test was conducted to check the instrument for clarity in direcrions and item wording. A small group of experienced faculty members were asked to take the questionnaire concentrating on the ease of responding to the instrument. Although their general feedback was positive but a few changes were made .The instrument was regarded as concise, simple an direct; it remained intact. 


\subsection{Pilot Study}

Following the item generation, panel review, field test, and revisions the 44 item questionnaire was piloted as an exploration of the measure and structure. The instrument was given to 127 faculty members at universities chosen through a convenience sampling. The purpose was to develop a set of reliable and valid measures for faculty members efficacy.The data were analyzed using a principal components analysis with a varimax rotation method. Initially, the items were forced into a four factor solutions, based on the theoretical framework used for item generation. However, the conceptual underpinnings of this solution were not supported, because all of the four components had items with high loading from more than one conceptual strand of faculty members efficacy.In order to make a more parsimonious solution, an additional principal component analysis was run with the following guidelines:

1. Unless there was a strong conceptual rationale to maintain items in subsequent analysis, items with high (above $0.40)$ loading on two or more factors were removed.

2. Item required a minimum loading of 0.40 on one factor to be remained.

3. It was attempted to obtain a parsimony or simple structure. So that items having high loadings be maintained.

Following the subsequent iterations of the principal component analysis, four dominant factors were emerged. It was discovered that the four sources of the conceptual framework were not indenpendent aspects of faculty members-efficacy.These factors explained $70 \%$ of the total variance and 18 items out of the 44 , remained (see Table 1).

It became apparent that conceptually factors that explained aspects of the faculty members-efficacy included: teaching competency, research competency, social competency and personal competency factors. The prevailing factors were found to contain virtually all of the four aspects of the faculty members-efficacy. Alpha coefficients was 0.83 totally, 0.83 for the teaching efficacy factor, 0.79 for the research efficacy factor, 0.78 for the social efficacy factor and 0.81 for the personal competency factor (see Table 3).

\section{Results of the Data Analysis}

The analysis produced four distinctive clusters of items: faculty perceptions about their teaching competencies, research competencies, social competencies and personal competencies. All items were loaded as was expected and the Cronbachs' Alpha reliability coefficients were acceptable: 0.83 for teaching efficacy, 0.79 for the research efficacy, 0.78 for social efficacy and 0.81 for personal competency.

Not surprisingly, these four dimensions were positively correlated (see Table 2), and formed a consistent archetype of efficacy for each referent cluster: teaching, research, social and personal competencies. Since a great care was taken to generate in each subset describing the four sources of efficacy, it was predictable that moderate correlations among the respective referents would emerge. We identified and subjected to factor analysis 18 items, which we predicted would define four aspects of faculty members-efficacy in higher education institutions. The factor analysis provided strong support for the construct validity of the measure.

In brief, the results of the data analysis demonstrate that the Faculty Member Efficacy Inventory (FMEI) is a parsimonious, reliable, and valid measure. The FMEI taps four critical aspects of efficacy in higher education.Hence, Faculty Member Efficacy Inventory (FMEI) is composed of four subsets: a 6-item subscale to measure teaching competency, a 4-item subscale to measure research competency, a 4-item subscale to measure social competency and a 4-item subscale to measure personal competency. Next, we explored some relationships between the four dimensions of faculty members-efficacy and some personal characteristics.

\section{Main Survey}

The main sample of this study was more diverse and larger than the pilot study. The data set against with Faculty Member Efficacy Inventory was tested from three different universities and 261 faculty members, contributed to the study and agreed to help collect the data.

\subsection{Faculty Members-Efficacy, Gender, and Academic Rank}

\subsubsection{Second question: Are there statistically significant differences between male and female faculty members-efficacy in selected public universities?}

To answer this research question, the mean scores on the four subscales were compared. The results revealed no significant differences between male $(n=187)$ and female $(n=63)$ faculty members on the four measuers of faculty members-efficacy (no responded=11). Regarding teaching competencies, females obtained a mean of 51.08 and males had a mean of $51.60(\mathrm{~F}=0.46, \mathrm{p}=0.57)$; With regard to research competencies, females obtained a mean of 
33.44 and males had a mean of $32.95(\mathrm{~F}=0.63, \mathrm{p}=0.43)$. Concerning social competencies, females obtained a mean of 35.00 and males had a mean of $34.51(\mathrm{~F}=0.76, \mathrm{p}=0.39)$ and regarding personal competencies, females had a mean of 31.68 and males had a mean of $31.54(\mathrm{~F}=0.05, \mathrm{p}=0.83$, see Table 4$)$.

4.1.2 Third question: Are there statistically significant differences between lecturer, assistant, associated and full professors faculty members-efficacy in selected public universities?

To address this question, a multivariate analysis of varience (MANOVA) was performed. Because no significant $\mathrm{F}$ was found $(\mathrm{F}=1.26, \mathrm{df}=3, \mathrm{p}=0.28)$, this demonstrated that there was no significant differences between academic ranks on the four subscales of faculty members-efficacy (see Table 5). For teaching competencies, there was no statistically significant differences based on academic rank $(\mathrm{F}=0.80, \mathrm{p}=0.49)$. This finding illustrated that academic rank didnot not produce differing levels of teaching competencies. Regarding research competencies, there were also no statistically significant differences based on academic ranks $(\mathrm{F}=1.64, \mathrm{p}=0.18)$. This finding illustrated that academic rank did not produce differing levels of research competencies. There were not also statistically significant differences on the basis of the ranks with regard to social competencies $(\mathrm{F}=0.73, \mathrm{p}=0.53)$. This finding illustrated that academic rank also did not produce differing levels of social competencies. Finally, similar to teaching, research and social competencies, academic rank did not produce differing levels of personal competencies $(\mathrm{F}=1.18, \mathrm{p}=0.32)$.

\section{Discussion}

Our factor analysis of the items relating to faculty members-efficacy in higher education institutions defined four relatively distinct factors. The first factor, teaching competencies, measured the degree to which faculty member have confidence in their abilities for effective teaching. The second factor, research competencies, measured the degree to which faculty members have confidence in their abilities for research in their scientific disciplines. The third factor, social competencies gauged the extent to which faculty members have believed in and motivated by their capabilities for interaction and performed relationships between other individuals in academic environment, and, the fourth factor personal competencies gauged the extent to which faculty members have believed in their capabilities to organize and execute actions required for goal attainments.

In examining faculty perceptions of faculty members-efficacy, some might think that males would be more efficacious than females. That was not the case in this study. When it comes to levels of efficacy in higher education institutions involving colleagues, gender was not an issue. This finding appeared to contradict the popular notion that men are from Mars and women are from Venus (Gray, 1993).

Other question was: Is there a statistically significant difference in the degree of faculty-efficacy between lecturer, assistant, associate, and full proffesors in selected public universities? There were no significant differences in perceived levels of efficacy among diferent academic rank. This finding suggests that as faculty members ascend through the academic rank they are likely to maintain their efficacy beliefs. But what issues and factors in higher education preclude the growth of efficacy? What organizational factors support or detract from the continued development and maintenanace of higher education efficacy? Indeed, this issue provides fertile ground for further study.

\section{Conclusion}

Although this research was exploratory, it underscored some important issues. First, a general index developed to assess the degree of faculty members-efficacy in higher education institutions and to measure the extent to which faculty members believed in their capabilities based on gender and academic rank. The index was tested to be reliable and stable. Second, the higher education efficacy measure is composed of four subtests: A teaching competency scale to measure the degree to which faculty member has confidence in their abilities for effective teaching. A research competency scale to measure the degree to which faculty member has confidence in their abilities for research in their scientific disciplines. A social competency scale to measure the extent to which faculty members has believed in and motivated by their intensions and capabilities for interaction and performed relationships between other individuals in academic environment, and, a personal competency scale to measure the extent to which faculty members has believed in their capabilities to organize and execute actions required for goal attainments. Finally, gender differences and academic rank were not evident when it came to faculty members-efficacy.

Self-efficacy is an important and key construct in the educational environment, then it suggested to carry out further investigation about it. It seems that performing research about self-efficacy is more crucial in the university environments and this is the starting the way.

\section{References}

Bandura, A. (1977a). Social Learning Theory. Englewood Cliffs .NJ: Prentice-Hall, Inc. 
Bandura, A. (1986). Social Foundations of Thought and Action: A Social Cognitive Theory. Englewood Cliffs. NJ: Prentice - Hall, Inc.

Bandura, A. (1993). Perceived Self - efficacy in cognitive development and functioning. Educational psychology, 28 (2):117-148. http://dx.doi.org/10.1207/s15326985ep2802-3.

Bandura, A. (1997). Self - efficacy: The exercise of control. New York: W, H. Freeman

Bandura, A. (2000). Exercise of Human Agency Through Collective Efficacy. Current Directions in Psychological Service, 9(3):75-78. http://dx.doi.org/10.1111/1467-8721.00064.

Bandura, A., Barbaranelli, C., Caprara, G., \& Pastorelli, C. (1996). Multifaceted impact of self- efficacy beliefs on academic functioning. Child Development, 67 (3), 206-222. http://dx.doi.org/10.1111/j.1467-8624-1996.tb01791.X.

Bandura, A., Barbaranelli, C., Caprara, G., \& Pastorelli, C. (2001). Self-efficacy beliefs as shapers of children's aspirations and career trajectories. Child Development, 72, 187-206. http://dx.doi.org/10.1111/1467-8624.00273.

Bong, M., \& Skaalvik, M.E. (2003). Academic Self-Concept and Self-Efficacy :How Different Are They Really? Educational Psychology Review. New York: 15, Iss. 1; P. 1.

Bouffard, T., \& Couture, N. (2003). Motivational profile and academic achievement among students enrolled in different schooling tracks. Educational Studies, 29, 19-38.

Brennan, M. D., Robison, C. K., \& Shaughnessy, M. F. (1996). Gender comparison of teachers' sense of efficacy. Psychological Reports, 78, 122. http://dx.doi.org/10.3102/00028312031003627

Fives, M., \& Looney, L. (2009). College instructors sense of teaching and collective efficacy. International Journal of Teaching in Higher Education, 20(2):182-191.

Gage, C.Q. (2003). The meaning and measure of school mindfulness: An exploratory analysis. Unpublished Dissertation. School of the Ohio State University. 69.

Gibson, S., \& Dembo, M. H. (1984). Teacher efficacy: A construct validation. Journal of Educational Psychology, 76, 569-582. http://dx.doi.org/10.1037/0022-0663.76.4.569

Goddard, R. D. (2001). Collective efficacy: A neglected construct in the study of schools and student achievement. Journal of Educational Psychology, 93 (3), 467-476. http://dx.doi.org/10.1037/0022-663.93.3.467.

Goddard, R. D., Hoy, W. K., \& Woolfolk Hoy, A. (2004). Collective efficacy beliefs: Theoretical developments, empirical evidence, and future directions. Educational Researcher, 33 (3), 3-13. http://dx.doi.org/10.3102/0013189X033003003.

Goddard, Roger. D. (1998). Effects of Collective Efficacy on Student Achievement in Urban Public Elementary Schools. Unpublished doctoral dissertation, Ohio State University, Ohio.

Gray, J. (1993). Men are from Mars, women are from Venus: A practical guide for improving communication and getting what you want in your relationships. New York: Harper-Collins.

Guskey, Thomas. R., \& Passaro, Perry. D. (1994). Teacher efficacy: A study of construct dimensions. American Educational Research Journal, 31, 627-643.

Heppner, M. J. (1992). An empirical investigation of the effects of a teaching practicum on prospective faculty. Journal of Counseling \& Development, 72,500-509.

Hoy, W. K., \& Woolfolk, A. E. (1993). Teachers' sense of efficacy and the organizational health of schools. The Elementary School Journal, 93(4),355-372. http://dx.doi.org/0013-5984/93/9304-0002501.00.

Hoye, W.K., \& Miskel, C.G. (2003). Educational Administration: Theory, Research \& Practice. New York: Random House.

Landino, R. A., \& Owen, S. V. (1988). Self-efficacy in university faculty. Journal of Vocational Behavior, 3(1), 1-14. http://dx.doi.org/10.1016/0001-879(88)90030-9.

Loup, K. S., Clarke, J., \& Ellett, C. D. (1997, March). Exploring dimensions of personal and organizational efficacy motivation: A study of teachers, social workers, and university faculty. Paper presented at the annual meeting of the American Educational Research Association, Chicago.

Marsh, H. W., Trautwein, U., Ludtke, O., \& Baumert, J. (2005). Academic self -concept, interest, grades, and standardized test scores: Reciprocal effects models of causal ordering. Child Development, 76, 397-416. http://dx.doi.org/10.1111/j.1467-8624.2005.00853.X.

Meijer, C. J. W., \& Foster, S. F. (1988). The effect of teacher self-efficacy on referral chance. Journal of Special 
Education, 22(3), 378-385. http://dx.doi.org/10.11771002246698802200309.

Moore, W., \& Esselman, M. (1992). Teacher efficacy, empowerment, and a focused instructional climate: Does student achievement benefit? Paper presented at the annual meeting of the American Educational Researcher Association, San Francisco.

Pajares, F. (1992). Teachers' beliefs and educational research: Cleaning up a messy construct. Review of Educational Research, 62(3), 307-332. http://dx.doi.org/10.3102/00346543062003307

Pajares, F. (2000). Schooling in America: myths, mixed messages, and good intentions. Lecture delivered at the Great teachers Lecture Series: Emory University, Cannon Chapel. Retrieved September, 25, 2004. [Online] Available: http://www.emory.edu/EDUCATION/mfp/pajaresgtl.html.

Pajares, F., \& Miller, D. (1995). Mathematics self-efficacy and mathematics performances: the need for specificity of assessment. Journal of Counseling Psychology, 42, 190- 198.

Paulsen, A. M., \& Betz. N.E. (2004). Basic confidence predictor of career decision- making self- efficacy. The Career Development Quarterly, 52, 354-362.

Petersen, K.S. (2008).Collective Efficacy and Faculty Trust: A Study of Social Processes in Schools. [Dissertation] University of Texas at San Antonio.

Preito, L. R., \& Meyers, S. A. (1999). Effects of training and supervision on the self-efficacy of Psychology graduate teaching assistants. Teaching of Psychology, 26, 264-266. http://dx.doi.org/ $10.1207 / \mathrm{s} 15328023 \mathrm{TOP} 260404$.

Rimm-Kaufman, S. E., \& Sawyer, B. E. (2004). Primary-grade teachers' self-efficacy beliefs, attitudes toward teaching and discipline and teaching practice priorities in relation to the responsive classroom approach. Elementary School Journal, 104, 321-341.

Ross, J. A., Hogaboam-Gray, A., \& Hannay, L. (2001). Effects of teacher efficacy on computer skills and computer cognitions of Canadian students in grades K-3. The Elementary School Journal, 102(2), 141-156. http://dx.doi.org/0013-5984/2002/10202-0003502.00.

Schoen, L. G., \& Winocur, S. (1988). An investigationof the self-efficacy of male and female academics.Journal of Vocational Behavior, 32, 307-320. http://dx.doi.org/10.1016/0001-8791(88) 90022-X.

Soodak, L. c., \& Podell, D. M. (1993a). Teacher efficacy and bias in special education referrals. Journal of Educational Research, 86(4), 247-253. http://dx.doi.org/10.1080/00220671.1993.9941836.

Soodak, L. c., \& Podell, D. M. (1993b). Teacher efficacy and student problem as factors in special education referral. Journal of Special Education, 27(1), 66-81. http://dx.doi.org/10.1177/002246699302700105.

Tschannen-Moran, M., \& Woolfolk Hoy, Anita. (2007). The differential antecedents of self- efficacy beliefs of novice and experienced teachers. Teaching and Teacher Education, 23(6), 944-956. http://dx.doi.org/01.1016/j.tate.2006.05.003.

Tschannen-Moran, M., \& Woolfolk-Hoy, Anita. (2001).Teacher efficacy: Capturing an elusive construct.Teaching and Teacher Education, 17(7), 783-805. http://dx.doi.org/10.1016/s0742-051X(01)00036-1.

Tschannen-Moran, Megan, \& Hoy, Wayne (1998). Trust in schools: A conceptual and empirical analysis. Journal of Educational Administration, 36(4), 334-352. http://dx.doi.org/10.1108/09578239810211518.

Tucker, C. M., \& Herman, K. C. (2002). Using culturally sensitive theories and research to meet the academic needs of low- income African American children. American Psychologist, 57, 762-773. http://dx.doi.org/ 10.1002/pits.10038.

Tucker, C. M., Porter, T., Reinke, W. M., Herman, K. C., Ivery, P. D., \& Mack, C. E. et al. (2005). Promoting teacher efficacy for working with culturally diverse students. Preventing School Failure, 50(1), 29-34. http://dx.doi.org/10-3200/PSFL.50.1.29-34.

Woolfolk-Hoy, Anita (2004). Self-efficacy in college teaching. Essays on Teaching Excellence: Toward the Best in the Academy, 15(7).

Young, K. J., \& Kline, T. J. B. (1996). Perceived selfefficacy, outcome-efficacy and feedback: Their effects on professors' teaching development motivation. Canadian Journal of Behavioral Sciences, 28, 43-51. http://dx.doi.org/10.1037/0006-400X.28.1.43. 
Table 1. Total Varienced Explained of Faculty Members Efficacy Factors

\begin{tabular}{|c|c|c|c|c|c|c|c|c|c|}
\hline \multirow{2}{*}{ Components } & \multicolumn{3}{|c|}{ Initial Eigenvalues } & \multicolumn{3}{|c|}{ Extration Sums of Squared Loading } & \multicolumn{3}{|c|}{ Rotation Sums of Squared Loading } \\
\hline & Cumultative $\%$ & $\begin{array}{l}\% \text { Of } \\
\text { Varience }\end{array}$ & Total & Cumultative $\%$ & $\begin{array}{l}\% \text { Of } \\
\text { Varience }\end{array}$ & Total & Cumultative $\%$ & $\begin{array}{l}\% \text { Of } \\
\text { Varience }\end{array}$ & Total \\
\hline $\begin{array}{l}\text { Research } \\
\text { competencies }\end{array}$ & 50.554 & 16.370 & 2.947 & 50.554 & 16.370 & 2.947 & 38.693 & 19.254 & 3.466 \\
\hline $\begin{array}{l}\text { Social } \\
\text { competencies }\end{array}$ & 61.900 & 11.346 & 2.042 & 61.900 & 11.346 & 2.042 & 55.566 & 16.972 & 3.055 \\
\hline $\begin{array}{l}\text { Personal } \\
\text { competencies }\end{array}$ & 70.912 & 9.012 & 1.622 & 70.912 & 9.012 & 1.622 & 70.912 & 15.247 & 2.745 \\
\hline
\end{tabular}

Table 2. Correlations among Faculty Members-Efficacy Components

\begin{tabular}{|l|l|l|l|l|}
\hline Efficacy Components & $\begin{array}{l}\text { Teaching } \\
\text { competencies }\end{array}$ & $\begin{array}{l}\text { Research } \\
\text { competencies }\end{array}$ & Social competencies & $\begin{array}{l}\text { Personal } \\
\text { competencies }\end{array}$ \\
\hline Teaching competencies & 1.00 & $0.59^{*}$ & $0.34^{*}$ & $0.50^{*}$ \\
\hline Research competencies & $0.59^{*}$ & 1.00 & $0.42^{*}$ & $0.49^{*}$ \\
\hline Social competencies & $0.34^{*}$ & $0.42^{*}$ & 1.00 & $0.45^{*}$ \\
\hline Personal competencies & $0.50^{*}$ & $0.49^{*}$ & $0.45^{*}$ & 1.00 \\
\hline
\end{tabular}

${ }^{*} \mathrm{P} \leq 0.001$

Table 3. Rotated Factors Matrix Factor: Analysis of Faculty Member-Efficacy Dimensions

\begin{tabular}{|c|c|c|c|c|c|}
\hline & Items & I & II & III & IV \\
\hline 1 & I have theoretical knowledge enough about the subject matters that I teach. & 0.841 & & & \\
\hline 2 & My educational experiences lead to more needed teaching skill in me. & 0.832 & & & \\
\hline 3 & I apply disciplinary procedures in class well. & 0.694 & & & \\
\hline 14 & I have mastery in providing and producing the teaching material and resources . & 0.642 & & & \\
\hline 7 & I believe that high level goals lead to teaching progress. & 0.575 & & & \\
\hline 4 & I have mastery in evaluation methods considering teaching methods. & 0.465 & & & \\
\hline 8 & My research abilities make research work enjoyable to me. & & 0.900 & & \\
\hline 16 & One of my good skills is providing and formulating books and articles. & & 0.897 & & \\
\hline 10 & $\begin{array}{l}\text { My capabilities in formulationg research projects lead to my scientific } \\
\text { achievement. }\end{array}$ & & 0.733 & & \\
\hline 12 & I do a good judgement if they assign me a research work for evaluation. & & 0.713 & & \\
\hline 11 & I creat a warm climate whenever I have social relation with students. & & & 0.955 & \\
\hline 18 & I have a fair social relationship with my peers. & & & 0.870 & \\
\hline 17 & The students are feeling comfort whenever the discuss their problems with me. & & & 0.848 & \\
\hline 15 & One of my abilities is directing and leading of discussions in meetings. & & & 0.631 & \\
\hline 5 & When I really try, I can get through most difficult students. & & & & 0.819 \\
\hline 9 & My acheivement in my job performance is due to my efforts.. & & & & 0.784 \\
\hline 6 & If the chairperson assigns me different courses, I will teach them successfully. & & & & 0.672 \\
\hline 13 & $\begin{array}{l}\text { My presentation skills in scientific meetings will encourage the audiences to listen } \\
\text { carefully to my lecture. }\end{array}$ & & & & 0.490 \\
\hline \multicolumn{2}{|c|}{ Alpha Coeficient (Totally 0.83 ) } & 0.83 & 0.79 & 0.78 & 0.81 \\
\hline
\end{tabular}


Table 4. Mean, Standard Deviation and MANOVA of sub scales of Faculty members efficacy based on Gender

\begin{tabular}{|l|l|l|l|l|l|l|}
\hline \multirow{2}{*}{ Statistical Indicator } & \multicolumn{2}{|l|}{ Female } & Male & \multirow{2}{*}{ F } & Sig \\
\cline { 2 - 4 } \cline { 7 - 8 } Efficacy Beliefs & Mean & SD & Mean & SD & & P $\leq 0.05$ \\
\hline Faculty member efficacy & 151.20 & 11.23 & 150.59 & 15.21 & 0.88 & 0.77 \\
\hline Teaching competencies & 51.08 & 4.60 & 51.60 & 5.42 & 0.46 & 0.57 \\
\hline Research competencies & 33.44 & 3.68 & 32.95 & 4.49 & 0.63 & 0.43 \\
\hline Social competencies & 35.00 & 3.43 & 34.51 & 4.03 & 0.73 & 0.39 \\
\hline Personal competencies & 31.68 & 3.83 & 31.54 & 4.65 & 0.05 & 0.83 \\
\hline
\end{tabular}

Table 5. Mean, Standard Deviation and MANOVA of subscales of Faculty Members Efficacy based on Academic Rank

\begin{tabular}{|c|c|c|c|c|c|c|c|c|c|c|}
\hline \multirow{2}{*}{$\begin{array}{l}\text { Statistical Indicator } \\
\text { Efficacy Beliefs }\end{array}$} & \multicolumn{2}{|c|}{ Adjunct } & \multicolumn{2}{|c|}{ Assistant } & \multicolumn{2}{|c|}{ Associated } & \multicolumn{2}{|c|}{ Full Professor } & \multirow{2}{*}{$\mathrm{F}$} & \multirow{2}{*}{$\begin{array}{l}\text { Sig } \\
\mathrm{P} \leq 0.05\end{array}$} \\
\hline & Mean & SD & Mean & SD & Mean & SD & Mean & SD & & \\
\hline Faculty member efficacy & 149.76 & 13.89 & 149.56 & 14.58 & 153.52 & 13.97 & 150.13 & 13.97 & 1.26 & 0.28 \\
\hline Teaching competencies & 50.58 & 5.57 & 51.29 & 5.18 & 52.20 & 5.32 & 51.29 & 4.92 & 0.80 & 0.49 \\
\hline Research competencies & 33.35 & 4.11 & 51.29 & 5.18 & 52.20 & 5.32 & 51.29 & 4.92 & 1.64 & 0.18 \\
\hline Social competencies & 35.15 & 4.23 & 34.29 & 4.03 & 35.73 & 3.74 & 34.75 & 3.19 & 0.73 & 0.53 \\
\hline Personal competencies & 30.69 & 4.52 & 31.38 & 4.56 & 32.30 & 3.83 & 31.16 & 5.05 & 1.18 & 0.32 \\
\hline
\end{tabular}

